\title{
Giant rodents from the Neotropics: diversity and dental variation of late Miocene neoepiblemid remains from Urumaco, Venezuela
}

\author{
Juan D. Carrillo' ${ }^{1}$ Marcelo R. Sánchez-Villagra' ${ }^{1}$
}

Received: 9 December 2014/ Accepted: 27 April 2015/Published online: 10 May 2015

(C) Paläontologische Gesellschaft 2015

\begin{abstract}
Caviomorphs constitute a large evolutionary radiation of South America rodents, exhibiting a wide range of body size and ecomorphological disparity. The geological history of caviomorphs has been recorded mainly from high latitudes, besides isolated discoveries from the Neotropics. The late Miocene fauna from Urumaco, Venezuela, is noteworthy for its location and for preserving the giant rodent Phoberomys pattersoni. Previous studies of isolated postcranial remains suggested that the rodent diversity from Urumaco was higher than is currently recognized. Based on new remains we document dental variation that indicates the presence of at least two giant rodent taxa in Urumaco, including Neoepiblema. Quantitative analysis of dentition of the different neoepiblemid species supports the differentiation between Neoepiblema and Phoberomys and suggests that several recognized species of Phoberomys could represent different ontogenetic stages of one or few taxa within the genus.
\end{abstract}

Keywords Mammalia - Caviomorpha - South America . Neogene $\cdot$ Body size $\cdot$ Paleobiology

Kurzfassung Die Caviomorpha stellen eine grosse evolutionäre Radiation südamerikanischer Nagetiere dar. Die geologische Geschichte der Caviomorpha ist, neben isolierten Entdeckungen in der Neotropis, hauptsächlich von den hohen Breiten überliefert. Die spätmiozäne Fauna von

Marcelo R. Sánchez-Villagra

m.sanchez@pim.uzh.ch

Juan D. Carrillo

juan.carrillo@pim.uzh.ch

1 Paläontologisches Institut und Museum, Universität Zürich, Karl-Schmid-Strasse 4, 8006 Zurich, Switzerland
Urumaco, Venezuela, ist bemerkenswert für ihre Lage und für die Erhaltung von Phoberomys pattersoni. Vorhergehende Studien isolierter postcranialer Überreste deuteten darauf hin, dass die Diversität der Riesennager von Urumaco größer war als gegenwärtig angenommen. Basierend auf neuen Überresten dokumentieren wir dentale Variation, die auf die Anwesenheit von mindestens zwei verschiedenen Riesennager-Taxa in Urumaco, einschliesslich Neoepiblema, hinweist. Eine quantitative Analyse des Gebisses der verschiedenen neoepiblemiden Arten unterstützt die Unterscheidung zwischen Neoepiblema und Phoberomys, und deutet darauf hin, da $\beta$ verschiedene anerkannte Arten von Phoberomys unterschiedliche ontogenetische Stadien eines oder mehrerer Taxa innerhalb einer Gattung repräsentieren könnten.

Schlüsselwörter Mammalia $\cdot$ Caviomorpha . Südamerika · Neotropis · Neogen · Körpergröße · Paläobiologie

$\begin{array}{ll}\begin{array}{l}\text { Abbreviations } \\ \text { AMU-CURS }\end{array} & \begin{array}{l}\text { Alcaldía del Municipio de Urumaco, } \\ \text { Falcón, Venezuela } \\ \text { CIAAP-UNEM }\end{array} \\ & \begin{array}{l}\text { Antro de Investigaciones } \\ \text { Paleontónicas Arqueológicas y }\end{array} \\ & \begin{array}{l}\text { Experimental Francisco de Miranda, } \\ \text { Coro, Venezuela }\end{array} \\ & \text { Museo Nacional de Ciencias, Caracas, } \\ \text { MCNC } & \text { Venezuela } \\ \text { MLP } & \begin{array}{l}\text { Museo de La Plata, La Plata, Argentina } \\ \text { MACN }\end{array} \\ & \text { Buenos Argentino de Ciencias Naturales, } \\ \text { SALMA } & \text { South American land mammal age } \\ \text { M-m } & \text { Molar }\end{array}$




$\begin{array}{ll}\text { P-p } & \text { Premolar } \\ \text { AP } & \text { Anteroposterior length } \\ \text { AW } & \text { Anterior width } \\ \text { PW } & \text { Posterior width } \\ \text { MW } & \text { Medium width }\end{array}$

\section{Introduction}

Caviomorphs constitute a large radiation of South America rodents, exhibiting a wide range of body size and morphological disparity, including terrestrial, fossorial, semiaquatic, scansorial and arboreal representatives (Mares and Ojeda 1982; Weisbecker and Schmid 2007). The group likely arrived from Africa by rafting, with the first appearance of a stem caviomorph recorded in the middle Eocene of the Peruvian Amazonia (Yahuarango Formation; 41.6-40.94 Ma; Antoine et al. 2012). The molecular evidence and fossil record support the appearance of main clades ('superfamilies/families') within Caviomorpha during the late Eocene to early Oligocene (Vucetich et al. 1999; Fabre et al. 2012; Voloch et al. 2013), whereas most of the living 'families' radiated between the middle and late Miocene (Vucetich et al. 1999; Opazo 2005; Pérez and Pol 2012; Upham and Patterson 2012).

The long history of caviomorphs has been recorded, as is the general case from South America, from high latitudes (e.g., Wood and Patterson 1959; Vucetich et al. 1993, 1999, 2010a, b, 2014; Kramarz and Bellosi 2005; Flynn et al. 2008; Rinderknecht and Blanco 2008; Nasif et al. 2013), but the northern Neotropics have also provided significant discoveries (MacFadden 2006). The tropical faunas of Santa Rosa (late Eocene; Campbell 2004) and Contamana (middle Eocene; Antoine et al. 2012) of Peru, La Venta in the middle Miocene (Laventan SALMA) of Colombia (Kay et al. 1997), Urumaco in the late Miocene of Venezuela (SánchezVillagra et al. 2010) and Acre (Solimões Formation) in the middle to late Miocene of Amazonia (Cozzuol 2006; Ribeiro et al. 2013) are noteworthy, because of the diversity they preserve. The new tropical fossil assemblages of Fitzcarrald in middle Miocene (Laventan) sediments of the Peruvian Amazonia (Tejada-Lara et al. 2015) and Castilletes middle Miocene-early Pliocene in northern Colombia (Moreno et al. 2015) add important data to the Neotropical fossil record. The Greater Antilles have also been a source of significant discoveries (MacPhee 2011; MacPhee and Flemming 2003). As in northern South America, the most remarkable aspect of some Caribbean rodents has been their very large size (Silva Taboada et al. 2007).
Among the caviomorphs the Neoepiblemidae, including Neoepiblema, Eusigmomys and Phoberomys (Negri and Ferigolo 1999), are among the largest ones. Phylogenetic analyses suggest a close relationship between Phoberomys and Dinomys, the pacarana, among extant taxa (SánchezVillagra et al. 2003; Horovitz et al. 2006), but the phylogenetic relationships of these and other extinct and large caviomorphs are in need of study (Kramarz et al. 2013). Phylogenetic analyses based on molecular data support the close affinities between Dinomyidae and Chinchillidae (Opazo 2005; Huchon et al. 2007; Blanga-Kanfi et al. 2009; Fabre et al. 2012; Upham and Patterson 2012).

Phoberomys pattersoni is the largest neoepiblemid and is known based on an almost completed skeleton from the late Miocene deposits of the Urumaco Formation (Mones 1980; Bondesio and Bocquentin-Villanueva 1988; Sánchez-Villagra et al. 2003; Horovitz et al. 2006). Body mass estimates resulted in extreme sizes ranging from 220 to $450 \mathrm{~kg}$ (Millien and Bovy 2010; Geiger et al. 2013). Previous studies suggested that giant rodent diversity from Urumaco was higher than is currently recognized, either based on a few craniodental remains (Horovitz et al. 2006, 2010) or on isolated femora that cannot be used for definitive taxonomic assignations (Geiger et al. 2013). The taxonomy of these rodents is based largely on dental features (Table 1). There are size and morphological intraspecific variations in euhypsodont teeth, which are important to consider in order to understand the taxonomy and ontogeny of these rodents (Vucetich et al. 2005; Deschamps et al. 2007), an aspect that has been largely ignored so far because of the lack of appropriate samples.

Another caviomorph rodent documented for the Urumaco Formation includes an unidentified species of the dinomyid Eumegamys (Pascual and Díaz de Gamero 1969). Furthermore, faunal lists from Urumaco have included dental remains referred to Tetrastylus, Telicomys and Potamarchinae cf. Potamarchus and Olenopsis (Linares 2004). However, a revision of the referred specimens has not been done and most of these records are in need of verification (Horovitz et al. 2010). Geiger et al. (2013) distinguished four different morphotypes of giant caviomorphs from Urumaco based on an analysis of the femoral morphological variation and growth.

Neoepiblemids have been recorded in middle and late Miocene deposits of Brazil, Argentina and Peru (Horovitz et al. 2010; Tejada-Lara et al. 2015) (Fig. 1). An almost complete cranium and several mandibular remains of Neoepiblema ambrosettianus have been described for the late Miocene of Acre, Brazil (Bocquentin-Villanueva et al. 1990; Negri and Ferigolo 1999). Rodents are one of the most diverse groups registered in the Acre region with ten genera and twelve species, eleven of which are neoepiblemids and dinomyids (Ribeiro et al. 2013; 
Table 1 Summary of dental traits, age and geographic distribution of the recognized members of Phoberomys and Neoepiblema

\begin{tabular}{|c|c|c|c|c|}
\hline Taxon & Dental traits & Locality & Age & Reference \\
\hline $\begin{array}{l}\text { Phoberomys Kraglievich } \\
1926\end{array}$ & $\begin{array}{l}\text { M3 with seven to eight laminae united } \\
\text { labially, p4 with four laminae, the first } \\
\text { two or three united labially and the third } \\
\text { or fourth or just the fourth free }\end{array}$ & & & $\begin{array}{l}\text { Bondesio and Bocquentin- } \\
\text { Villanueva (1988) }\end{array}$ \\
\hline $\begin{array}{l}\text { Phoberomys insolita } \\
\text { Kraglievich } 1940\end{array}$ & M3 with eight laminae united labially & $\begin{array}{l}\text { Mesopotamia, } \\
\text { Argentina }\end{array}$ & $\begin{array}{l}\text { Late Miocene } \\
\text { (Huayquerian) }\end{array}$ & Kraglievich 1940 \\
\hline $\begin{array}{l}\text { Phoberomys pattersoni } \\
\text { Mones } 1980\end{array}$ & $\begin{array}{l}\text { M3 with seven laminae united labially. P4 } \\
\text { with four laminae, the two anterior ones } \\
\text { united labially, the posterior ones free }\end{array}$ & Urumaco, Venezuela & Late Miocene & $\begin{array}{l}\text { Bondesio and Bocquentin- } \\
\text { Villanueva (1988), Mones } \\
\text { (1980) }\end{array}$ \\
\hline $\begin{array}{l}\text { Phoberomys lozanoi } \\
\text { Kraglievich } 1926\end{array}$ & $\begin{array}{l}\text { M3 with eight laminae united labially, the } \\
\text { eighth one is poorly developed and not } \\
\text { visible in oclusal view }\end{array}$ & $\begin{array}{l}\text { Mesopotamia, } \\
\text { Argentina }\end{array}$ & $\begin{array}{l}\text { Late Miocene } \\
\text { (Huayquerian) }\end{array}$ & Kraglievich (1940) \\
\hline $\begin{array}{l}\text { Phoberomys burmeisteri } \\
\text { Kraglievich } 1926\end{array}$ & $\begin{array}{l}\mathrm{p} 4 \text { with four laminae, the two anterior } \\
\text { ones united labially and two posterior } \\
\text { ones free }\end{array}$ & $\begin{array}{l}\text { Mesopotamia, } \\
\text { Argentina and Acre, } \\
\text { Brazil }\end{array}$ & $\begin{array}{l}\text { Late Miocene } \\
\text { (Huayquerian) }\end{array}$ & Kraglievich $(1926,1932)$ \\
\hline $\begin{array}{l}\text { Phoberomys praecursor } \\
\text { Kraglievich (1932 }\end{array}$ & $\begin{array}{l}\text { p4 with four laminae, the three anterior } \\
\text { ones united labially and fourth one free }\end{array}$ & $\begin{array}{l}\text { Mesopotamia, } \\
\text { Argentina }\end{array}$ & $\begin{array}{l}\text { Late Miocene } \\
\text { (Huayquerian) }\end{array}$ & Kraglievich (1932) \\
\hline $\begin{array}{l}\text { Phoberomys bordasi } \\
\text { Patterson } 1942\end{array}$ & $\begin{array}{l}\text { p4 with four laminae, the three anterior } \\
\text { ones united labially and the fourth free }\end{array}$ & Acre, Brazil & $\begin{array}{l}\text { Late Miocene } \\
\text { (Huayquerian) }\end{array}$ & Patterson (1942) \\
\hline $\begin{array}{l}\text { Phoberomys minima } \\
\text { Kraglievich } 1940\end{array}$ & $\begin{array}{l}\text { Lower molars smaller than } P \text {. lozanoi and } \\
\text { larger than Neoepiblema }\end{array}$ & $\begin{array}{l}\text { Mesopotamia, } \\
\text { Argentina and Acre, } \\
\text { Brazil }\end{array}$ & $\begin{array}{l}\text { Late Miocene } \\
\text { (Huayquerian) }\end{array}$ & Kraglievich (1940) \\
\hline $\begin{array}{l}\text { Neoepiblema Ameghino } \\
1889\end{array}$ & $\begin{array}{l}\text { M3 with four laminae united labially, p4- } \\
\text { m3 with three laminae, the first two } \\
\text { united labially and the third free. In the } \\
\text { p4 the third prism free or united } \\
\text { lingually to the second }\end{array}$ & & & Negri and Ferigolo (1999) \\
\hline $\begin{array}{l}\text { Neoepiblema } \\
\text { ambrossetianus } \\
\text { Ameghino } 1889\end{array}$ & $\begin{array}{l}\text { Molars larger than } N \text {. horridula. Second } \\
\text { and third laminae of P4-M3 more } \\
\text { transversal than } N . \text { horridula }\end{array}$ & $\begin{array}{l}\text { Mesopotamia, } \\
\text { Argentina and Acre, } \\
\text { Brazil }\end{array}$ & $\begin{array}{l}\text { Late Miocene } \\
\text { (Huayquerian) }\end{array}$ & $\begin{array}{l}\text { Negri and Ferigolo (1999), } \\
\text { Bocquentin-Villanueva } \\
\text { et al. (1990) }\end{array}$ \\
\hline $\begin{array}{l}\text { Neoepiblema horridula } \\
\text { Ameghino } 1889\end{array}$ & As for the genus & $\begin{array}{l}\text { Mesopotamia, } \\
\text { Argentina and Acre, } \\
\text { Brazil }\end{array}$ & $\begin{array}{l}\text { Late Miocene } \\
\text { (Huayquerian) }\end{array}$ & Ameghino (1889) \\
\hline
\end{tabular}

Kerber et al. 2015). The late Miocene sediments from the Paraná region, Argentina, include terrestrial mammals from the Ituzaingó Formation, which counts under its rodent fauna several members of the Neoepiblemidae (Phoberomys and Neoepiblema) (Cione et al. 2000; Nasif et al. 2013). Additional records of Neoepiblemidae include Neoepiblema sp. in Fitzcarrald, Peru (Tejada-Lara et al. 2015), and the San Gregorio Formation, Pliocene of Venezuela (Vucetich et al. 2010c).

In this work we describe new dental and cranial remains of giant rodents from the Urumaco Formation providing evidence of a higher rodent diversity and morphological disparity than previously recognized. We quantify the dental size variation in Phoberomys and Neoepiblema, and we show that the morphological variation in neoepiblemid rodents from Urumaco does not just represent intraspecific variation within $P$. pattersoni, the only species from this group previously described for the Urumaco fauna.

\section{Materials and methods}

We investigated the dentition of neoepiblemid specimens from Urumaco, Venezuela, and Mesopotamia, Argentina, as well as different taxa described in the literature. In order to have a clear view of the occlusal surface of the dentition, we sectioned the upper and lower dentition of ten specimens from Urumaco. We first stabilized the samples surrounding the teeth with the resin Technovit ${ }^{\circledR}$ 5071, and we cut the dentition with a sawblade along the anteroposterior axis, at about $50 \mathrm{~mm}$ from the occlusal surface. For each tooth available, we measured the anteroposterior length (AP), anterior width (AW), posterior width (PW) and medium width (MW). For the M3, as it has multiple laminae, we only measured the AP and PW. Measurements were taken with calipers to the nearest $0.1 \mathrm{~mm}$. For the dental terminology we follow Negri and Ferigolo (1999) and Bondesio and Bocquentin-Villanueva (1988). Our use 


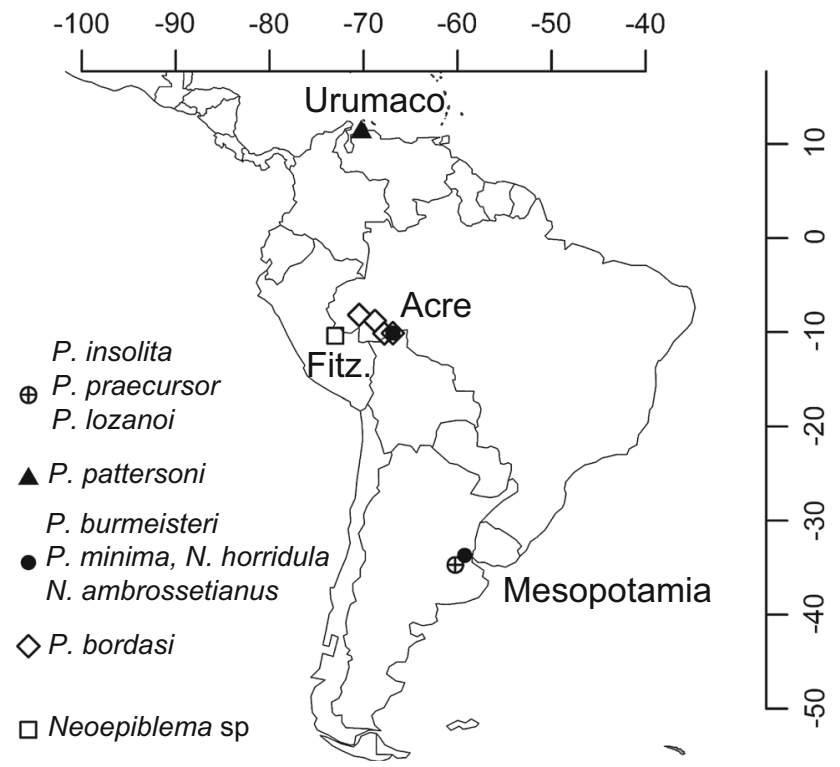

Fig. 1 Distribution of Phoberomys and Neoepiblema in South America. Fitz Fitzcarrald. Data downloaded from the Paleobiology database on 26 November 2014 using group names = Phoberomys, Neoepiblema , region $=$ South America

of the term "laminae" is equivalent to "prisms" as used by Mones (1980).

For the quantitative analysis of the dentition, we performed a bivariate plot of the logarithm $(\log )$ of AW vs. $\log$ of AP. We grouped in the analysis the P4-M2 for the upper dentition and $\mathrm{m} 1-\mathrm{m} 3$ for the lower dentition because they are morphologically indistinguishable when dealing with isolated teeth. We did a linear regression for each set of teeth. The plots and regressions were made with $\mathrm{R}(\mathrm{R}$ core team 2014).

\section{Systematic paleontology}

Rodentia Bowdich, 1821

Hystricognathi, Tullberg, 1899

Chinchilloidea Bennett, 1833

Neoepiblemidae, Kraglievich, 1926

Neoepiblema Ameghino, 1889

Neoepiblema $\mathrm{sp}$.

Material AMU-CURS 381, partial left dentary with p4m3.

Provenance NW San Rafael $\left(11^{\circ} 14^{\prime} 52^{\prime \prime} \mathrm{N}, 70^{\circ} 14^{\prime} 06^{\prime \prime} \mathrm{W}\right)$, Urumaco Formation, upper member (Fig. 2).

Description AMU-CURS 381 has three laminae in the p4, the two anterior ones united labially and the third one free, as Neoepiblema (Negri and Ferigolo 1999). The mandibular symphysis extends posteriorly up to the middle anterior portion of $\mathrm{p} 4$, as described for $N$. ambrosettianus
(Mones and Toledo 1989), but also true for $P$. pattersoni (AMU-CURS 53 and AMU-CURS 170, see below). AMUCURS 381 have only three laminae in $\mathrm{p} 4$, in contrast with Phoberomys that has four, the first two connected labially (Bondesio and Bocquentin-Villanueva 1988). The m1-m3 of AMU-CURS 381 have three laminae, all of them free (Fig. 3a); in contrast to the other species of Neoepiblema that have three laminae in the lower molars, the second connected labially to the first and the third free (Negri and Ferigolo 1999). AMU-CURS 381 differs from some specimens referred to Neoepiblema ambrosettianus in having the third prism of the $\mathrm{p} 4$ free and not connected lingually to the second (Mones and Toledo 1989; Bocquentin-Villanueva et al. 1990).

We assigned AMU-CURS 381 to Neoepiblema based on the morphology and number of laminae of the $\mathrm{p} 4$. The fact that the $\mathrm{m} 1-\mathrm{m} 3$ of AMU-CURS 381 have three free laminae suggests that the labial connection between the first and second prism in $\mathrm{m} 1-\mathrm{m} 3$ is a variable character for Neoepiblema

Phoberomys Kraglievich, 1926

Phoberomys sp. A

Material AMU-CURS 382, partial left mandible with $\mathrm{p} 4$ only preserved at the alveolar level and $\mathrm{m} 1-\mathrm{m} 3$ poorly preserved. UNEFM-VF 014, with this catalog number, there are two partial mandibles, one right dentary with p4m3, which we refer to Phoberomys sp. A, and a second right dentary with m1-m3 identified as Phoberomys sp.

Provenance AMU-CURS 382 comes from NW San Rafael $\left(11^{\circ} 14^{\prime} 52^{\prime \prime} \mathrm{N}, 70^{\circ} 14^{\prime} 06^{\prime \prime} \mathrm{W}\right)$, Urumaco Formation, upper member (Fig. 2). UNEFM-VF 014 comes from Urumaco Formation, Urumaco.

Description AMU-CURS 382 and UNEFM-VF 014 exhibit features described for both Phoberomys and Neoepiblema. The p4 has four laminae, the two anterior ones connected labially and the third and fourth free, as in P. pattersoni and P. burmeisteri (Kraglievich 1926, 1932; Bondesio and Bocquentin-Villanueva 1988) (Fig. 3b). Due to its preservation it is difficult to observe the number and pattern of laminae in $\mathrm{m} 1$ and $\mathrm{m} 2$ for AMU-CURS 382; however, it is possible to state they are three, and they all seem to be free as in Phoberomys. In UNEFM-VF 014, the m1-m2 have three free laminae. The $\mathrm{m} 3$ has three laminae, the two anterior ones connected labially, as in Neoepiblema (Negri and Ferigolo 1999). The molar dimensions of these specimens are small compared to specimens referred to $P$. pattersoni (Table 2).

In contrast with AMU-CURS 382 and UNEF-VF 014, the $\mathrm{p} 4$ of $P$. bordasi and $P$. praecursor has the three anterior laminae united labially and the fourth free (Kraglievich 1932; Patterson 1942). These specimens differ 

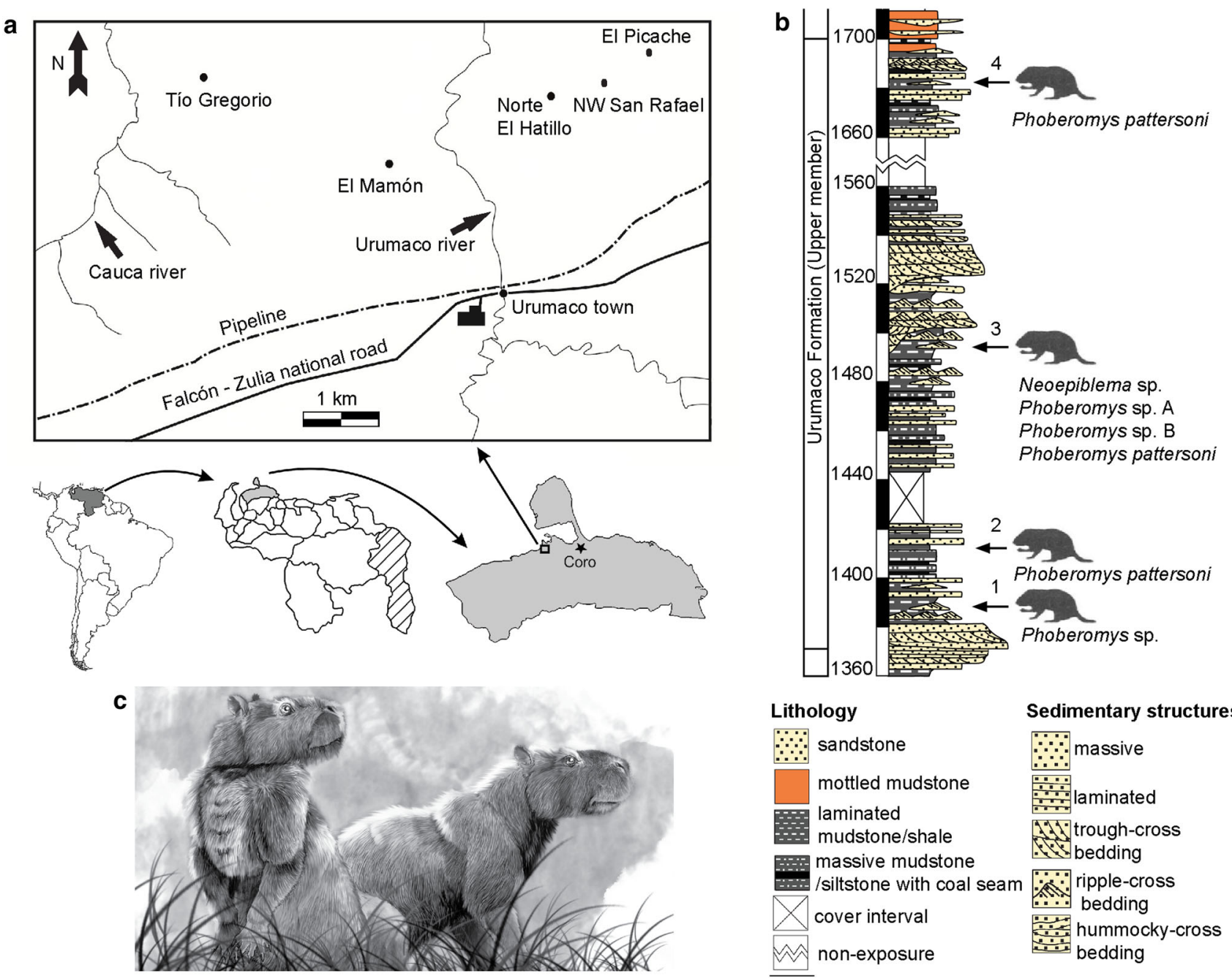

Fig. 2 Geographic and stratigraphic occurrence of neoepiblemids from Urumaco; a fossil localities and $\mathbf{b}$ stratigraphic profile of the upper member of the Urumaco Formation; the taxonomic occurrence of neoepiblemid taxa is indicated for each locality: (1) El Hatillo, (2)
El Mamón, (3) El Picache/NW San Rafael and (4) Tío Gregorio/Cerro José La Paz. Modified from Quiroz and Jaramillo (2010) and Scheyer et al. (2013); c restoration of $P$. pattersoni. Artwork by Jorge González, modified from Horovitz et al. (2010) from Neoepiblema in that the p4 of the latter has only three laminae (Negri and Ferigolo 1999). We therefore assigned AMU-CURS 382 and UNEFM-VF 014 to Phoberomys based on the morphology and laminae of the $\mathrm{p} 4$. The labial connection between the first and second laminae in $\mathrm{m} 3$ is a variable character in Phoberomys and neoepiblemids in general, as was mentioned above for AMU-CURS 381 referred to Neoepiblema sp.

\section{Phoberomys sp. B}

Material AMU-CURS 380-maxilla with right M1-M3 and left M3. AMU-CURS 35, partial maxilla with right P4-M3 and left P4-M1. MCN 66-72 V, isolated M3.

Provenance AMU-CURS 380 comes from NW San Rafael $\left(11^{\circ} 14^{\prime} 52^{\prime \prime} \mathrm{N}, 70^{\circ} 14^{\prime} 06^{\prime \prime} \mathrm{W}\right)$, Urumaco Formation, upper member. AMU-CURS 35 comes from El Picache,
Urumaco Formation, upper member (Fig. 2). MCN $66-72 \mathrm{~V}$ is from Urumaco Formation, Urumaco.

Description AMU-CURS 380 shows some diagenetic deformation, as the maxilla is slightly folded toward the left side. It preserves the right M1-M3 and the left M3. It is not possible to observe clearly the morphology of laminae in M1, but it has three laminae connected labially in M2. AMU-CURS 35 shows the P4-M2 with three laminae connected labially.

AMU-CURS 380, AMU-CURS 35 and MCN 66-72 V differ from other specimens of Phoberomys in the number of laminae of M3. The M3 of these specimens have six laminae (Fig. 3f, g), all connected labially, and it narrows posteriorly. In contrast, the M3 of other Phoberomys species have seven to eight laminae connected labially (Bondesio and Bocquentin-Villanueva 1988). The relative 
a

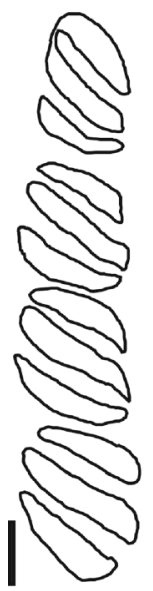

Neoepiblema sp. p4-m3

f

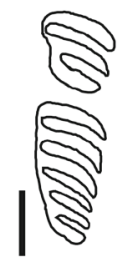

Phoberomys sp. B M2-M3 b

C

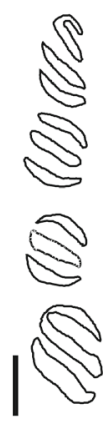

Phoberomys sp. A p4-m3

g

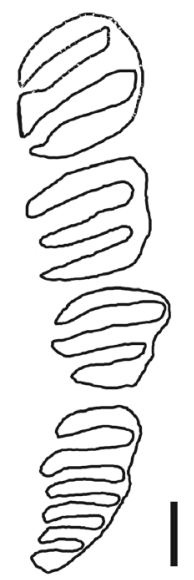

Phoberomys sp. B P4-M3 d

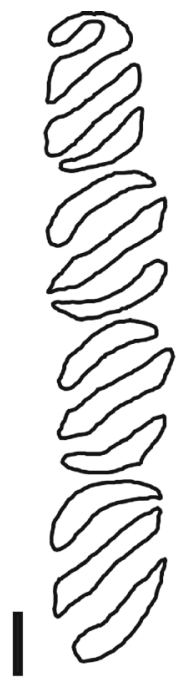

P. pattersoni p4-m2

h

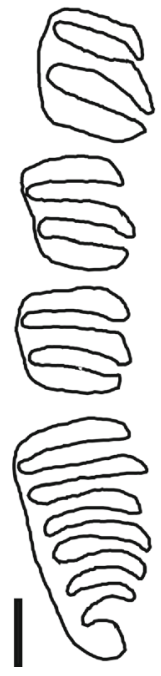

P. pattersoni

P4-M3 e
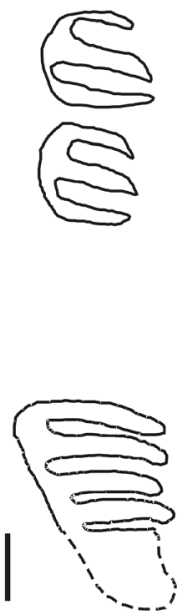

P. pattersoni p4-m3

Phoberomys sp. P4-M1, M3 i

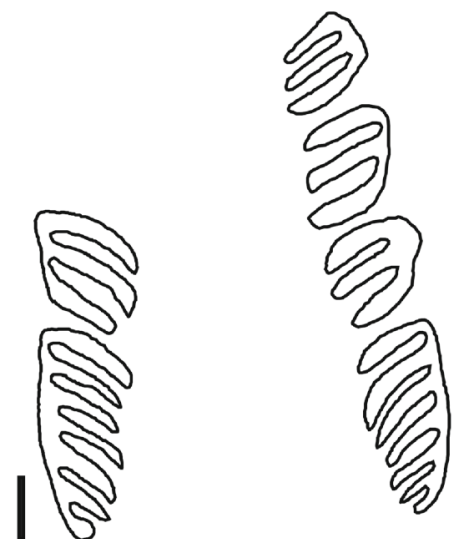

P. pattersoni

right M2-M3 and left P4-M3
Fig. 3 Occlusal surface morphology of the neoepiblemids from Urumaco. a Lower dentition Neopiblema sp. (AMU-CURS 381); b lower dentition Phoberomys sp. A, (AMU-CURS 382); c lower dentition $P$. pattersoni (AMU-CURS 454); d lower dentition $P$. pattersoni (AMU-CURS 170); e upper dentition Phoberomys sp. (AMU-CURS 161); dashed lines represent the portion of M3 where

dimensions of the dentition of these specimens are small compared to other specimens referred to Phoberomys (Table 2).

\section{Phoberomys sp.}

Material AMU-CURS 161-complete cranium compressed in the dorsal-ventral plane.

Provenance AMU-CURS 161 comes from Norte El Hatillo, Urumaco Formation, upper member (Fig. 2). the occlusal morphology could not be observed; $\mathbf{f}$ upper dentition Phoberomys sp. B (AMU-CURS 380); g upper dentition Phoberomys sp. B (AMU-CURS 35); h upper dentition P. pattersoni (AMU-CURS 255); i upper dentition P. pattersoni (AMU-CURS 53). Scale bar $10 \mathrm{~mm}$

Description AMU-CURS 161 is tentatively assigned to Phoberomys because it presents more than four laminae connected labially in the M3, although is not possible to assess the total number of laminae because of the preservation of the posterior portion of the M3. Phoberomys has 7-8 laminae in M3 (Bondesio and Bocquentin-Villanueva 1988); in contrast Neoepiblema have only four laminae (Negri and Ferigolo 1999). The P4-M1 of AMU-CURS 161 have three laminae connected labially as in all 
Table 2 Dental measurements of neoepiblemids

\begin{tabular}{|c|c|c|c|c|c|c|c|c|c|c|}
\hline \multirow[t]{3}{*}{ Taxon } & \multirow[t]{3}{*}{ Catalog number } & \multirow[t]{3}{*}{ Tooth } & \multicolumn{4}{|l|}{ Left } & \multicolumn{4}{|l|}{ Right } \\
\hline & & & \multirow{2}{*}{$\begin{array}{l}\text { Length } \\
\text { AP }\end{array}$} & \multicolumn{3}{|c|}{ Width } & \multirow{2}{*}{$\begin{array}{l}\text { Length } \\
\text { AP }\end{array}$} & \multicolumn{3}{|c|}{ Width } \\
\hline & & & & AW & PW & MW & & AW & PW & MW \\
\hline \multirow[t]{18}{*}{ Phoberomys sp. } & AMU-CURS 161 & P4 & & & & & 15.6 & 12.9 & 16.1 & 15.7 \\
\hline & & M1 & & & & & 18.2 & 17.2 & 14.8 & 15 \\
\hline & & M2 & & & & & 17.5 & 19.6 & 16.4 & $?$ \\
\hline & & M3 & & & & & 27.3 & 20.7 & 11.4 & NA \\
\hline & UNEFM TG4 & $\mathrm{P} 4$ & & & & & 28.6 & 28.5 & 22.1 & $?$ \\
\hline & & M1 & & & & & 21.1 & 21.6 & 20.6 & 21 \\
\hline & & M2 & & & & & 19.3 & 23.5 & 20.3 & 22.2 \\
\hline & & M3 & & & & & 41.1 & 22 & 13.1 & NA \\
\hline & UNEFM 1438 & M1 & 17.7 & 16.2 & 13.7 & 15 & & & & \\
\hline & & M2 & 19.3 & 17 & 14.1 & 18 & & & & \\
\hline & MACN-Pv 2645 & p4 & & & & & 11.6 & 7.4 & 7.6 & 8.3 \\
\hline & UNEFM-VF 014 & $\mathrm{~m} 1$ & & & & & 20.7 & 14.8 & 14.7 & 16.7 \\
\hline & & $\mathrm{m} 2$ & & & & & 22.6 & 16.8 & 19.3 & 17.6 \\
\hline & & $\mathrm{m} 3$ & & & & & 26.2 & 18.3 & 17.6 & 21.8 \\
\hline & MACN-Pv 3475 & $\mathrm{~m} 1-\mathrm{m} 3$ & & & & & 25.4 & 20.6 & 20.9 & 23.7 \\
\hline & CIAAP $1438^{\mathrm{b}}$ & M1 & 16.9 & 17 & & & & & & \\
\hline & & M2 & 18.3 & 18.3 & & & & & & \\
\hline & & $\mathrm{m} 2$ & & & & & 22.6 & 16.5 & & \\
\hline \multirow[t]{8}{*}{ Phoberomys sp. A } & AMU-CURS 382 & p4 & 17 & $?$ & 12.8 & $?$ & & & & \\
\hline & & $\mathrm{m} 1$ & 15.2 & 9.9 & 11.7 & $?$ & & & & \\
\hline & & $\mathrm{m} 2$ & 15.9 & 8.6 & 10.7 & 10.8 & & & & \\
\hline & & $\mathrm{m} 3$ & 19.7 & 10.4 & 10.5 & 9.6 & & & & \\
\hline & UNEFM-VF 014 & p4 & & & & & 15 & 14.8 & 10.9 & 11.9 \\
\hline & & $\mathrm{m} 1$ & & & & & 14 & 11.7 & 12 & 12.2 \\
\hline & & $\mathrm{m} 2$ & & & & & 15.4 & 12.2 & 11.7 & 13.5 \\
\hline & & $\mathrm{m} 3$ & & & & & 15.3 & 11.5 & 11.8 & 13.2 \\
\hline \multirow[t]{8}{*}{ Phoberomys sp. B } & AMU-CURS 380 & M1 & 15.4 & 13 & 9.9 & $?$ & & & & \\
\hline & & M2 & 13 & 12.8 & 8.3 & 11.7 & & & & \\
\hline & & M3 & 23.1 & 12.2 & 5.5 & NA & & & & \\
\hline & AMU-CURS 35 & $\mathrm{P} 4$ & 24.1 & 13.9 & 18.1 & 14.1 & & & & \\
\hline & & M1 & 20.5 & 17.2 & 15.4 & 17 & & & & \\
\hline & & M2 & 16.6 & 16.9 & $?$ & $?$ & & & & \\
\hline & & M3 & 28.2 & 13.5 & 7.6 & NA & & & & \\
\hline & MCNC 66-72 V & M3 & 15.1 & 9.1 & 6.7 & NA & & & & \\
\hline \multirow[t]{3}{*}{ P. insolita } & MACN-Pv 13480 & P4-M2 & 17 & 20.2 & 20.3 & 21.4 & & & & \\
\hline & MACN-Pv 4068 & $\mathrm{P} 4-\mathrm{M} 2$ & 21.5 & 22.2 & 19.6 & 21.8 & & & & \\
\hline & MACN-Pv 3290 & $\mathrm{P} 4-\mathrm{M} 2$ & & & & & 22.2 & 21.9 & 22 & 22.7 \\
\hline \multirow[t]{13}{*}{ P. pattersoni } & AMU-CURS 255 & $\mathrm{P} 4$ & 21.3 & 13.5 & 12.8 & $?$ & 21.4 & 11 & 11 & $?$ \\
\hline & & M1 & 19.2 & 16.6 & 14.8 & $?$ & 18.6 & 13.2 & 14.4 & $?$ \\
\hline & & M2 & 17 & 16.2 & 14.1 & $?$ & 18.5 & 15.5 & 15 & $?$ \\
\hline & & M3 & 33.5 & 14.3 & 6.4 & NA & 36.6 & 20.4 & 9.9 & NA \\
\hline & MCNC $12-72 \mathrm{~V}$ & M3 & 33.6 & 17.1 & 7.1 & NA & & & & \\
\hline & AMU-CURS 39 & $\mathrm{P} 4$ & 25.2 & 22.4 & 24.6 & 22.5 & 26.5 & 19.8 & 22.7 & 22.7 \\
\hline & & M1 & 26.5 & 21 & 22.3 & 24.4 & 19.9 & 19.5 & 20.3 & 22.4 \\
\hline & & M2 & 22.2 & 20 & 21 & 23.6 & 19.6 & 22.5 & 19.1 & 20.8 \\
\hline & & M3 & 48 & 22.4 & 20.4 & NA & 49.3 & 22.4 & 13.3 & NA \\
\hline & & p4 & & & & & 32.7 & 14.2 & 21.1 & 21.4 \\
\hline & & $\mathrm{m} 1$ & & & & & $?$ & $?$ & $?$ & 23.4 \\
\hline & & $\mathrm{m} 2$ & & & & & 26 & 25.2 & 22.6 & $?$ \\
\hline & & $\mathrm{m} 3$ & & & & & 29.3 & 26.8 & 27.4 & 26.2 \\
\hline
\end{tabular}


Table 2 continued

\begin{tabular}{|c|c|c|c|c|c|c|c|c|c|c|}
\hline \multirow[t]{3}{*}{ Taxon } & \multirow[t]{3}{*}{ Catalog number } & \multirow[t]{3}{*}{ Tooth } & \multicolumn{4}{|l|}{ Left } & \multicolumn{4}{|l|}{ Right } \\
\hline & & & \multirow{2}{*}{$\begin{array}{l}\text { Length } \\
\text { AP }\end{array}$} & \multicolumn{3}{|c|}{ Width } & \multirow{2}{*}{$\begin{array}{l}\text { Length } \\
\text { AP }\end{array}$} & \multicolumn{3}{|c|}{ Width } \\
\hline & & & & AW & PW & MW & & AW & PW & MW \\
\hline & AMU-CURS 53 & P4 & 26.1 & 15.1 & 17.3 & $?$ & $?$ & $?$ & 17.6 & $?$ \\
\hline & & M1 & 22.9 & $?$ & 15.5 & $?$ & 21.8 & 17.6 & 16 & $?$ \\
\hline & & M2 & 22 & 18.8 & 14 & 17.1 & 21.8 & 17.7 & 12.5 & 17 \\
\hline & & M3 & 38.5 & 15 & 10.5 & NA & 42.3 & 18.4 & 9 & NA \\
\hline & & $\mathrm{p} 4$ & 26.4 & 14.6 & 15.2 & $?$ & & & & \\
\hline & & $\mathrm{m} 1$ & 25.9 & 14.9 & 13 & $?$ & & & & \\
\hline & & $\mathrm{m} 2$ & 25.6 & 15.2 & 13.6 & $?$ & & & & \\
\hline & & $\mathrm{m} 3$ & 26.4 & 15.5 & 11.4 & $?$ & & & & \\
\hline & AMU-CURS 454 & $\mathrm{p} 4$ & 31.9 & 12.6 & 28.3 & 13.4 & & & & \\
\hline & & $\mathrm{m} 1$ & 23.5 & 18.2 & 20.4 & 21.4 & & & & \\
\hline & & $\mathrm{m} 2$ & 25.5 & 19.4 & 23.9 & 22.2 & & & & \\
\hline & & $\mathrm{m} 3$ & 27.5 & 24.1 & 17.5 & $?$ & & & & \\
\hline & AMU-CURS 170 & $\mathrm{p} 4$ & & & & & 25.5 & 11.6 & 14.7 & 15.3 \\
\hline & & $\mathrm{m} 1$ & & & & & 23.7 & 15.2 & 18.5 & 18.8 \\
\hline & & $\mathrm{m} 2$ & & & & & 24.3 & 15.2 & 18.5 & 18.8 \\
\hline & & $\mathrm{m} 3$ & & & & & 27.6 & 17.8 & 14.4 & 16.5 \\
\hline & MCNC 104-72 V & $\mathrm{m} 3$ & 36.9 & 22.4 & 22 & 26.6 & & & & \\
\hline & UNEFM-VF $020^{\mathrm{b}}$ & $\mathrm{P} 4$ & & & & & 27.9 & 20.8 & & \\
\hline & & M1 & & & & & 20.6 & 21 & & \\
\hline & & M2 & & & & & 18.6 & 21 & & \\
\hline & & M3 & & & & & 41 & 20.7 & & \\
\hline P. praecursor & MACN-Pv 9026 & $\mathrm{p} 4$ & 28.7 & 11.8 & 22.2 & 19.4 & & & & \\
\hline \multirow[t]{10}{*}{ P. burmeisteri } & MACN-A 5831 (Type) & P4-M2 & 21 & 23.8 & 26 & 31.4 & & & & \\
\hline & MLP 15-254 & $\mathrm{p} 4$ & & & & & 33.3 & 24.2 & 22.5 & 22.3 \\
\hline & MLP 15-257 & $\mathrm{p} 4$ & & & & & 32.8 & 21.1 & 24.5 & 22 \\
\hline & MACN-Pv 4729 & $\mathrm{p} 4$ & & & & & 30.8 & 12.8 & 19.5 & 20.2 \\
\hline & MLP 12-246 & $\mathrm{m} 1$ & 23.8 & 20.3 & 21 & 20.5 & & & & \\
\hline & & $\mathrm{m} 2$ & 25.3 & 20.8 & 21.6 & 21.8 & & & & \\
\hline & & $\mathrm{m} 3$ & 32 & 22.2 & 23 & 21.2 & & & & \\
\hline & MACN-Pv 2494 & $\mathrm{~m} 3$ & & & & & 36.8 & 24.4 & 28 & 28.8 \\
\hline & MACN-Pv 6620 & $\mathrm{~m} 1-\mathrm{m} 3$ & 28.6 & 20.5 & 22.5 & 20.4 & & & & \\
\hline & MACN-Pv 3288 & $\mathrm{~m} 1-\mathrm{m} 3$ & & & & & 26.6 & 20.2 & 24 & 23.7 \\
\hline P. lozanoi & $\operatorname{MLP} 36^{\mathrm{c}}$ & M3 & 34 & 14.5 & 8.5 & NA & & & & \\
\hline \multirow[t]{2}{*}{ P. bordasi } & AMNH $22666^{\mathrm{f}}$ & $\mathrm{p} 4$ & & & & & 16.4 & 4 & 13.3 & 13.7 \\
\hline & & $\mathrm{m} 1$ & & & & & 16.5 & 12 & 14.5 & 15.7 \\
\hline P. minima & MACN-Pv 3461 & P4-M2 & 13.7 & 12.8 & 12.7 & 15.7 & & & & \\
\hline \multirow[t]{9}{*}{ Neoepiblema sp. } & MLP 73-I-10-2 & P4-M2 & & & & & 11.7 & 9 & 10.5 & 9.9 \\
\hline & AMU-CURS 381 & $\mathrm{p} 4$ & 22 & 15 & 14 & 14.6 & & & & \\
\hline & & $\mathrm{m} 1$ & 18.8 & 14.7 & 16.6 & 14.5 & & & & \\
\hline & & $\mathrm{m} 2$ & 18.3 & 17 & 18.6 & 19 & & & & \\
\hline & & $\mathrm{m} 3$ & 23.5 & 18.5 & 17 & 19.7 & & & & \\
\hline & MLP 15-420a & $\mathrm{m} 1-\mathrm{m} 3$ & 10.3 & 5.8 & 7.7 & 8.3 & & & & \\
\hline & MLP 15-419a & $\mathrm{m} 1-\mathrm{m} 3$ & 10.5 & 7.7 & 8.9 & 8.6 & & & & \\
\hline & MLP 15-421 & $\mathrm{m} 1-\mathrm{m} 3$ & 12.4 & 8.5 & 11.6 & 9.7 & & & & \\
\hline & MLP 41-XII-13-4102 & $\mathrm{m} 1-\mathrm{m} 3$ & & & & & 13.4 & 11.7 & 11.7 & 11.6 \\
\hline
\end{tabular}


Table 2 continued

\begin{tabular}{|c|c|c|c|c|c|c|c|c|c|c|}
\hline \multirow[t]{3}{*}{ Taxon } & \multirow[t]{3}{*}{ Catalog number } & \multirow[t]{3}{*}{ Tooth } & \multicolumn{4}{|l|}{ Left } & \multicolumn{4}{|l|}{ Right } \\
\hline & & & \multirow{2}{*}{$\begin{array}{l}\text { Length } \\
\text { AP }\end{array}$} & \multicolumn{3}{|c|}{ Width } & \multirow{2}{*}{$\begin{array}{l}\text { Length } \\
\text { AP }\end{array}$} & \multicolumn{3}{|c|}{ Width } \\
\hline & & & & AW & PW & MW & & AW & PW & MW \\
\hline \multirow[t]{15}{*}{ N. horridula } & MACN-Pv 2609 & P4 & & & & & 12.4 & 8.5 & 8.7 & 10.2 \\
\hline & & M1 & & & & & 11.8 & 9.2 & 8 & 9.8 \\
\hline & & M2 & & & & & 11.9 & 9.2 & 7.8 & 9.8 \\
\hline & & M3 & & & & & 15.7 & 9 & 4.6 & NA \\
\hline & MLP 69-XII-2-20 (Type) & M3 & & & & & 12.6 & 5.6 & 7.2 & NA \\
\hline & MACN-Pv 13414 & M3 & 14.9 & 8.8 & 5.9 & NA & & & & \\
\hline & MACN-Pv 15318 & M3 & & & & & 10 & 5.9 & 3.4 & NA \\
\hline & MLP 73-I-10-4 & P4-M2 & & & & & 7.1 & 4 & 4.8 & 4.7 \\
\hline & MACN-Pv 13365 & P4-M2 & 10.5 & 8 & 7.6 & 8.4 & & & & \\
\hline & MACN-Pv 13362 & P4-M2 & & & & & 10 & 7.9 & 9.4 & 10.2 \\
\hline & MACN-Pv 9036 & P4-M2 & 11.6 & 8.9 & 7.4 & 8.6 & & & & \\
\hline & MACN-Pv 4504 & P4-M2 & 9.8 & 8.6 & 7.3 & 8.8 & & & & \\
\hline & MACN A 5874 & P4-M2 & 8 & 7.7 & 7.4 & 7.7 & & & & \\
\hline & MACN-Pv 3458 & P4-M2 & 11.5 & 8.5 & 7.9 & 8.6 & & & & \\
\hline & & M3 & 15.6 & 8.8 & 6.4 & NA & & & & \\
\hline \multirow[t]{33}{*}{ N. ambrossetianus } & MACN-Pv 4575 & P4-M2 & & & & & 12.4 & 13.7 & 20 & 17.3 \\
\hline & MACN-Pv 4580 & $\mathrm{~m} 1$ & & & & & 8.3 & 4.5 & 6.2 & 5.9 \\
\hline & & $\mathrm{m} 2$ & & & & & 7.8 & 5.4 & 6.4 & 6.5 \\
\hline & MACN-Pv 13473 (Type) & $\mathrm{m} 1$ & 13.5 & 7.7 & 10.4 & 10 & & & & \\
\hline & & $\mathrm{m} 2$ & 15.1 & 8.3 & 11.4 & 11.6 & & & & \\
\hline & MACN-Pv 4576 & $\mathrm{~m} 1-\mathrm{m} 3$ & & & & & 14.7 & 14.1 & 17.6 & 16 \\
\hline & MACN-Pv 4542 & $\mathrm{~m} 1-\mathrm{m} 3$ & & & & & 11 & 8.1 & 9.7 & 8.1 \\
\hline & MACN-Pv 4031 & $\mathrm{~m} 1-\mathrm{m} 3$ & & & & & 11.1 & 7.7 & 8.4 & 11.4 \\
\hline & MACN-Pv 8885 & $\mathrm{~m} 1-\mathrm{m} 3$ & 13.7 & 9.5 & 11.1 & 11.5 & & & & \\
\hline & MACN-Pv 3404 & $\mathrm{~m} 1-\mathrm{m} 3$ & & & & & 12.1 & 9.2 & 11.4 & 11.2 \\
\hline & MACN-A 5829 & $\mathrm{~m} 1-\mathrm{m} 3$ & 8.8 & 6.4 & 7.3 & 7.2 & & & & \\
\hline & MACN-A 5830 & $\mathrm{~m} 1-\mathrm{m} 3$ & 8.4 & 6.9 & 9.8 & 9.2 & & & & \\
\hline & MACN-Pv 2484 & $\mathrm{~m} 1-\mathrm{m} 3$ & 11.3 & 7.4 & 8.9 & 8.6 & & & & \\
\hline & MACN-Pv 4480 & $\mathrm{~m} 1-\mathrm{m} 3$ & & & & & 6 & 4 & 4.5 & 5 \\
\hline & MACN-Pv 3276 & $\mathrm{~m} 1-\mathrm{m} 3$ & 11.3 & 7.2 & 8.4 & 8.8 & & & & \\
\hline & MPEG PV-82 ${ }^{\mathrm{d}}$ & $\mathrm{p} 4$ & 15 & 9 & 10 & 12 & & & & \\
\hline & & $\mathrm{m} 1$ & 15.5 & & 13 & & & & & \\
\hline & & $\mathrm{m} 2$ & 15.1 & & 12 & & & & & \\
\hline & & $\mathrm{m} 3$ & 15.3 & 8 & 13 & & & & & \\
\hline & UFAC $4515^{\mathrm{e}}$ & $\mathrm{P} 4$ & 16 & 11.7 & 12 & 15 & 16 & 11.8 & 12 & 15.2 \\
\hline & & M1 & 15 & 12.8 & 14.4 & 11 & 15 & 13.1 & 11.5 & 14.7 \\
\hline & & M2 & 15 & 13.1 & 12 & 14.6 & 15 & 12.8 & 12 & 14.2 \\
\hline & & M3 & 22.2 & 12.2 & 10.2 & NA & 22 & 11.5 & 10.4 & NA \\
\hline & UFAC $1716^{\mathrm{a}}$ & M2 & & & & & 14 & 10.5 & & \\
\hline & & M3 & & & & & 21 & 10 & & \\
\hline & & $\mathrm{p} 4$ & 13.5 & 10 & & & & & & \\
\hline & & $\mathrm{m} 1$ & 12.5 & 11 & & & & & & \\
\hline & & $\mathrm{m} 2$ & 13 & 17 & & & & & & \\
\hline & & $\mathrm{m} 3$ & 10 & 11 & & & & & & \\
\hline & UFAC $1490^{\mathrm{a}}$ & $\mathrm{p} 4$ & & & & & 16 & 9 & & \\
\hline & & $\mathrm{m} 1$ & & & & & 13.5 & 10 & & \\
\hline & & $\mathrm{m} 2$ & & & & & 13.5 & 10 & & \\
\hline & & $\mathrm{m} 3$ & & & & & 15.5 & 11 & & \\
\hline
\end{tabular}


Table 2 continued

\begin{tabular}{|c|c|c|c|c|c|c|c|c|c|c|}
\hline \multirow[t]{3}{*}{ Taxon } & \multirow[t]{3}{*}{ Catalog number } & \multirow[t]{3}{*}{ Tooth } & \multicolumn{4}{|l|}{ Left } & \multicolumn{4}{|l|}{ Right } \\
\hline & & & \multirow{2}{*}{$\begin{array}{l}\text { Length } \\
\text { AP }\end{array}$} & \multicolumn{3}{|c|}{ Width } & \multirow{2}{*}{$\begin{array}{l}\text { Length } \\
\text { AP }\end{array}$} & \multicolumn{3}{|c|}{ Width } \\
\hline & & & & AW & PW & MW & & $\mathrm{AW}$ & PW & MW \\
\hline & UFAC $1658^{\mathrm{a}}$ & $\mathrm{p} 4$ & 17 & 11 & & & & & & \\
\hline & UFAC $1810^{\mathrm{a}}$ & $\mathrm{p} 4$ & & & & & 16 & 11.5 & & \\
\hline & & $\mathrm{m} 1$ & & & & & 16 & 13.5 & & \\
\hline & & $\mathrm{m} 2$ & & & & & 16 & 12 & & \\
\hline & & $\mathrm{m} 3$ & & & & & 19 & 11 & & \\
\hline
\end{tabular}

$A P$ anterior-posterior length, $A W$ anterior width, $P W$ posterior width, $M W$ medium width, $N A$ not applicable

${ }^{\text {a }}$ Bocquentin-Villanueva et al. (1990)

${ }^{\mathrm{b}}$ Horovitz et al. (2006)

c Kraglievich (1940)

${ }^{d}$ Mones and Toledo (1989)

e Negri and Ferigolo (1999)

${ }^{\mathrm{f}}$ Patterson (1942)

neoepiblemids (Fig. 3e). The preservation prevents observing the morphology of laminae in M2. AMU-CURS 161 presents a strong diagenetic compression in the dorsoventral plane and its bad preservation prevents observing most of the cranial sutures. The skull is long and narrow, with conspicuous sagittal and nuchal crests (Fig. 4). AMUCURS 161 shares some traits with Neoepiblema such as the ventral root of the zygomatic process at the level of $\mathrm{P} 4$, and palatines present at the level of the middle portion of M3; these traits were included in the generic diagnosis of Neoepiblema by Negri and Ferigolo (1999), but they are also present in P. pattersoni (e.g., AMU-CURS 255, see below).

AMU-CURS 161 shares some traits with $N$. ambrosettianus, including: premaxilar elongated forming more than half of the diastema and a prominent sagittal crest projecting over the other elements of the cranium (Negri and Ferigolo 1999). The presence of a sagittal crest in a specimen originally referred to $P$. pattersoni by Bondesio, and Bocquentin-Villanueva (1988) (CIAAP 1438) was also mentioned by Horovitz et al. (2006), who referred the specimen to cf. Phoberomys while highlighting several differences between CIAAP 1438 and other specimens of P. pattersoni.

Phoberomys pattersoni, Mones 1980

Material AMU-CURS 255, complete cranium compressed in the dorsal-ventral plane and the anterior portion of the rostrum folded toward the lateral right plane. AMU-CURS 53, maxilla with right and left $\mathrm{P} 4-\mathrm{M} 3$ and partial left dentary with $\mathrm{p} 4-\mathrm{m} 3$. AMU-CURS 454, partial left mandible ramus with $\mathrm{p} 4-\mathrm{m} 3$, poorly preserved. AMU-CURS 170, a complete mandible with right and left p4-m3.
Provenance AMU-CURS 255 comes from El Picache, Urumaco Formation, upper member; AMU-CURS 39 and AMU-CURS 53 are from El Mamón, Urumaco Formation, upper member; AMU-CURS 454 comes from Cerro Jose La Paz $\left(11^{\circ} 14^{\prime} 40^{\prime \prime} \mathrm{N}, 70^{\circ} 09^{\prime} 44.3^{\prime \prime} \mathrm{W}\right)$, Urumaco Formation, upper member and AMU-CURS 170 comes from Tío Gregorio, Urumaco Formation, upper member (Fig. 2).

Description AMU-CURS 255 is assigned to P. pattersoni based on the M3 with seven laminae connected labially (Fig. 3g) (Mones 1980; Bondesio and Bocquentin-Villanueva 1988) and the narrowing of the posterior portion of M3 at the level of the last three laminae (Mones 1980; Sánchez-Villagra et al. 2003). The P4-M2 have three laminae connected labially. The third lamina of P4 is concave anteriorly and has a "V" shape inflexion in its inner portion (Bondesio and Bocquentin-Villanueva 1988) (Fig. 3g). AMU-CURS 255 also presents a strong diagenetic distortion; it is compressed in the dorso-ventral plane, and the most anterior portion of the rostrum is folded toward the right lateral side (Fig. 4). Due to the preservation it is not possible to observe the cranial sutures. The skull does not show a well-developed sagittal crest as has been mentioned before for $P$. pattersoni (Sánchez-Villagra et al. 2003) and in contrast to N. ambrossetianus (Negri and Ferigolo 1999) and cf. Phoberomys (Horovitz et al. 2006). It is possible that the degree of development of the sagittal crest is related to age. AMU-CURS 255 has the anterior root of the zygomatic arch at the level of $\mathrm{P} 4$ as in $N$. ambrossetianus (Negri and Ferigolo 1999) and cf. Phoberomys (Horovitz et al. 2006).

AMU-CURS 53 is also assigned to $P$. pattersoni based on the number of laminae and morphology of the M3 (Fig. 3i). The P4-M2 have three laminae all connected 
labially, as in all neoepiblemids. Although the specimen consists of a complete lower left dentition, the preservation of the specimen prevents the examination of diagnostic features of $P$. pattersoni in the $\mathrm{p} 4$. The $\mathrm{m} 1-\mathrm{m} 3$ have three laminae, apparently all free. AMU-CURS 454 and AMUCURS 170 are identified as $P$. pattersoni based on the $\mathrm{p} 4$ morphology with four laminae, the two anterior ones connected labially and $\mathrm{m} 1-\mathrm{m} 3$ with three laminae, all free (Fig. 3c, d) (Bondesio and Bocquentin-Villanueva 1988). In AMU-CURS 53 and AMU-CURS 170, the mandibular symphysis extends posteriorly, reaching the anterior portion of the $\mathrm{p} 4$.

\section{Quantitative analysis}

The relationship between the anteroposterior length (AP) and anterior width (AW) of the upper and lower dentition in Phoberomys and Neoepiblema is different in the two genera, with Neoepiblema having a lower length to width ratio than Phoberomys, although the two taxa are within the same trajectory (Fig. 5a-d). For Neoepiblema we found that $N$. horridula is smaller than $N$. ambrossetianus and the dental morphospace of the two species does not overlap (Fig. 5a, b). Within Phoberomys, there is no clear differentiation of the dental morphospace among species (Fig. 5a-d).

For the M3 (Fig. 5a), there are two specimens assigned to Phoberomys sp. B (MCN 66-72 V and AMU-CURS 380), which overlaps with Neoepiblema; besides its small size, these specimens have six laminae in the M3. For the P4-M2 (Fig. 5b) and lower dentition (Fig. 5c, d), there is also a small overlap between the two genera. However, the overall pattern is the same, with Neoepiblema being smaller than Phoberomys and both genera falling within the same trajectory.

\section{Discussion}

Most of the neoepiblemid species currently recognized as valid are known from isolated or fragmentary upper or lower dentitions (for a summary of the systematic history of Neoepiblemidae, see Bondesio and Bocquentin-Villanueva, 1988: 32-33 and Negri and Ferigolo, 1999: 8-12). The most important characteristics considered for species definition within the group have been the number and morphology of laminae in premolars and molars and the relative molar size (e.g., Kraglievich 1940; Mones 1980; Patterson 1942). However, rodents with euhypsodont teeth have a wide range of ontogenetic and intraspecific morphological variation (Vucetich et al. 2005), which calls for caution for the definition of new taxa based on fragmentary material without an appropriate sample size. We found for example that the pattern of labial connections among the laminae in $\mathrm{m} 1-\mathrm{m} 3$ is a variable character in Phoberomys and Neoepiblema and should not be used as a characteristic to differentiate the two genera.

Until now, P. pattersoni and Eumegamys were the only big rodent taxa formally reported for the Urumaco Formation. We found evidence to support the recognition of a higher diversity of giant rodents from Urumaco and report for the first time the presence of Neoepiblema in this Formation. Vucetich et al. (2010c) reported Neoepiblema sp. for the San Gregorio Formation (late Pliocene) toward the top of the Urumaco sequence from an assemblage that also includes hydrochoerids and an octodontoid. The record of Neoepiblema in the Urumaco Formation confirms the presence of this taxon in the northern Neotropics since the late Miocene. The oldest record of Neoepiblema comes from the middle Miocene Fitzcarrald fauna (Tejada-Lara et al. 2015). Until now, no rodents from the Socorro Formation (middle Miocene) in the Uumaco sequence had been reported. In an expedition in January 2015, one of us (MRSV) found a distal femur (AMU-CURS 641) of a giant rodent from the Socorro Formation. It is from East of Capirote $\left(11^{\circ} 11^{\prime} 32.9^{\prime \prime} \mathrm{N}, 70^{\circ} 11^{\prime} 22.4^{\prime \prime} \mathrm{W}\right)$, the road to Quebrada Honda, the same locality reported by Head et al. (2006: 234) for snakes.

Previous work in the late Miocene deposits of Acre, in southern Brazil and Paraná, and in northern Argentina shows a high diversity of rodents. Given the postulated similarity of the Urumaco mammal assemblage with the Acre and, to a lesser extent, the Paraná assemblages (Cozzuol 2006; Carrillo et al. 2015), a higher diversity than recognized until now for Urumaco was only expected. This conclusion is supported by the previous study of morphological diversity in postcranial remains (Geiger et al. 2013).

The length-width relationship in the dentition shows a differentiation between the two neoepiblemid genera, with Neoepiblema having a lower length-to-width ratio than Phoberomys. Within Neoepiblema, N. horridula is smaller than $N$. ambrossetianus, and there is no overlap between the two species. In the case of Phoberomys, there is not a clear differentiation among the different species recognized within the genus, and they overlap along the trajectory of the dental morphospace, suggesting that some of these species could represent different ontogenetic stages of one or few taxa within Phoberomys, as has also been proposed for hydrochoerids (Vucetich et al. 2005; Deschamps et al. 2013). The possibility that the number of neoepiblemid species is lower than currently recognized has also been raised by other authors (Vucetich et al. 2010c; Nasif et al. 2013). 


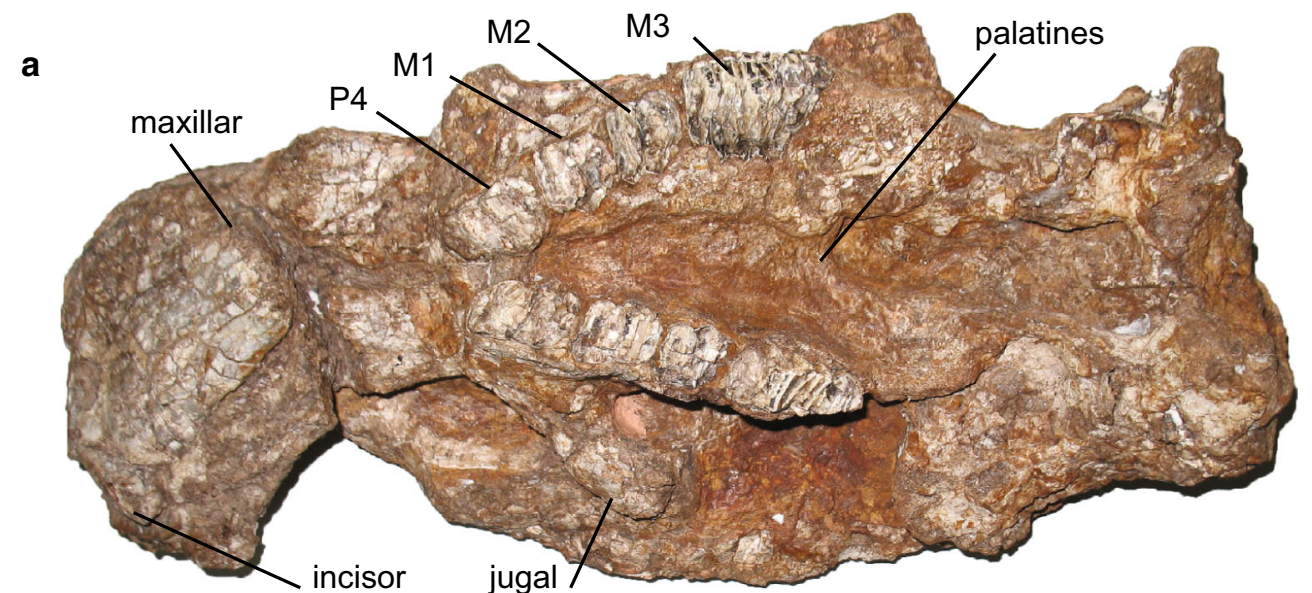

b

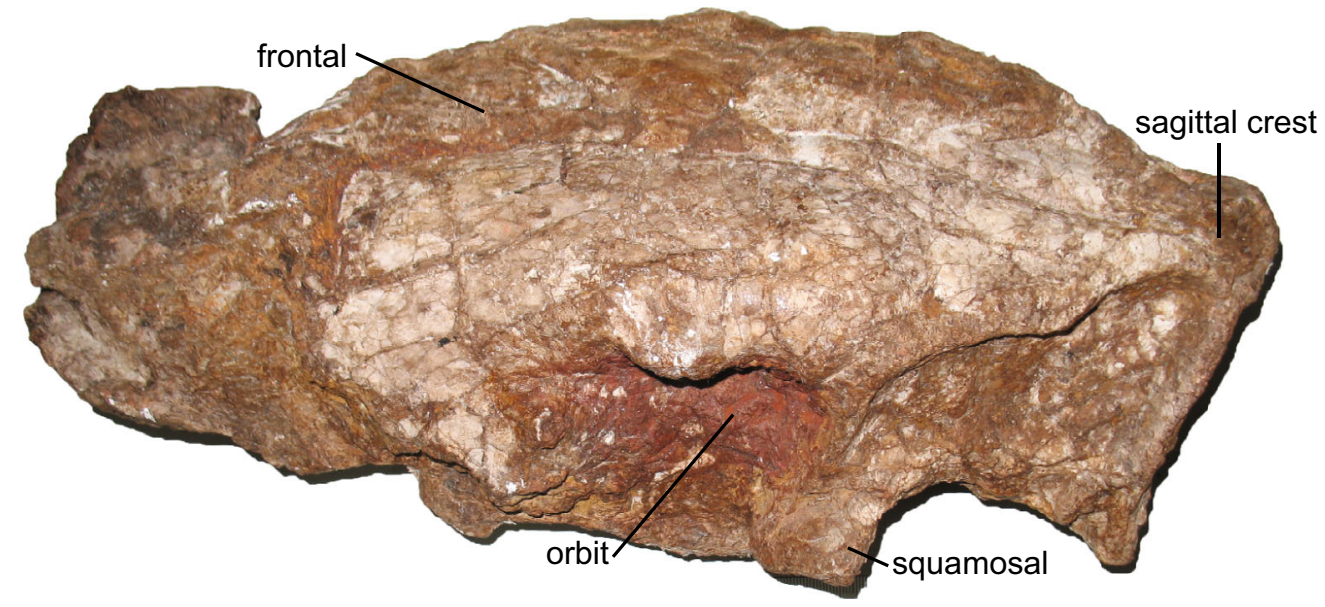

C

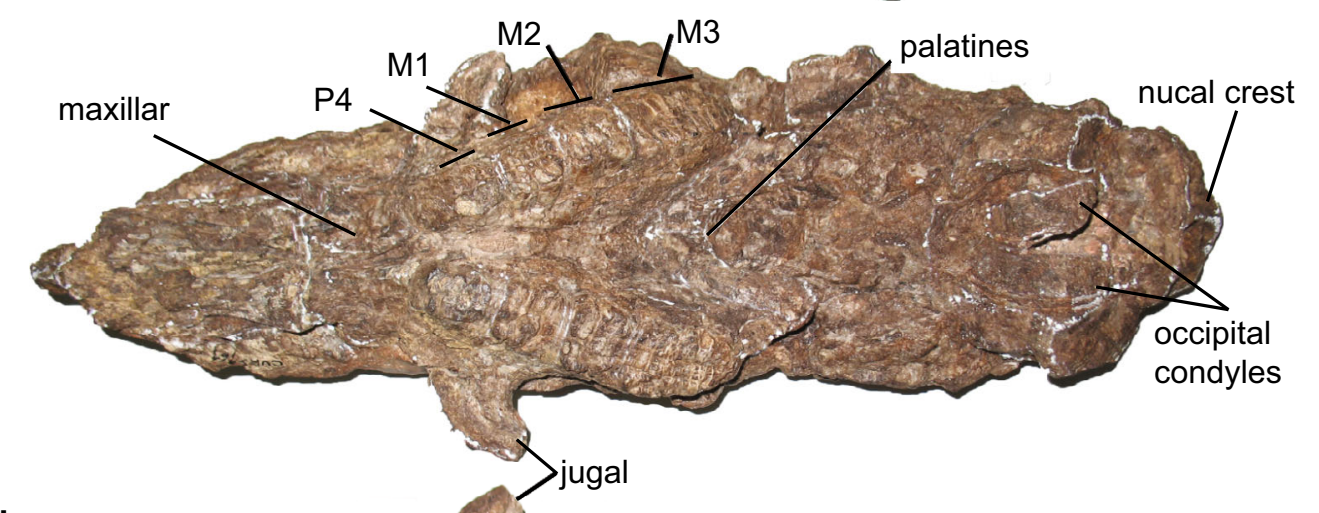

d

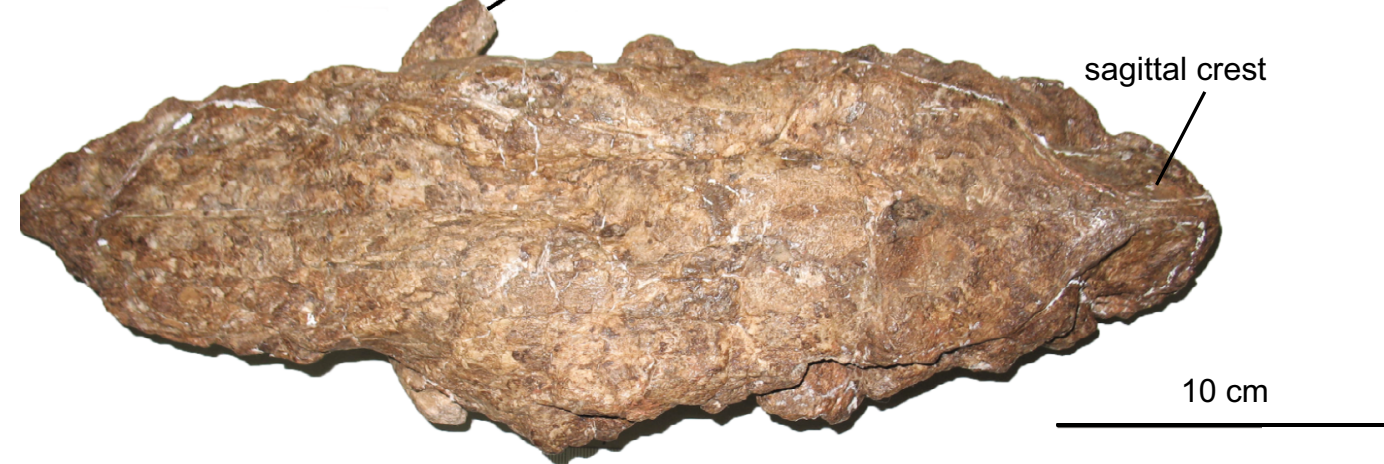

Fig. 4 Neoepiblemid skulls from Urumaco. P. pattersoni (AMU-CURS 255) a ventral view; b dorsal view. Phoberomys sp. (AMU-CUS 161) c ventral view; d dorsal view 

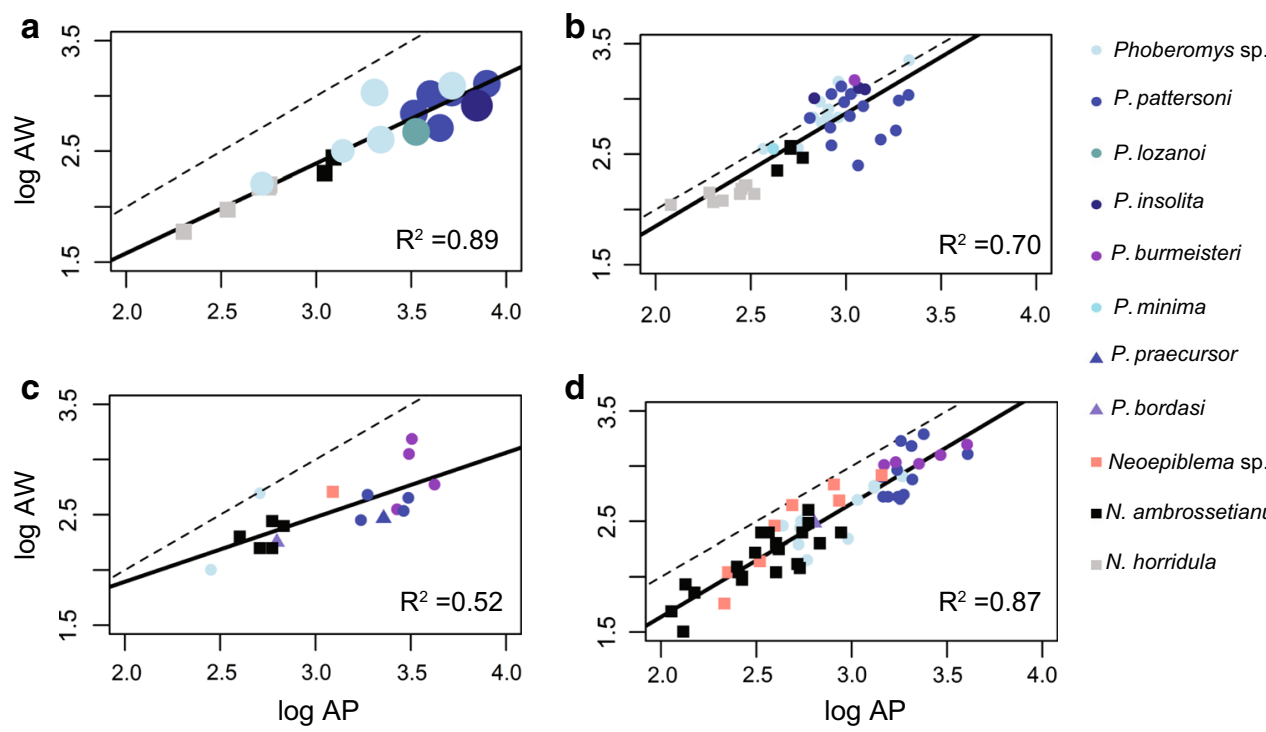

d

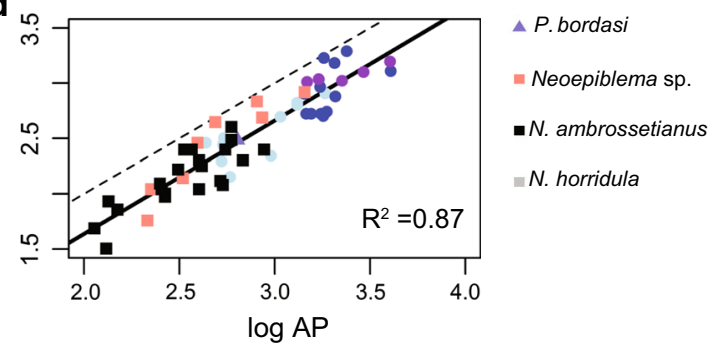

Fig. 5 Length-width relationship of the upper and lower dentition in Neoepiblemidae. a M3, the dot size is proportional to the number of laminae. b P4-M2. c p4, the dot size is proportional to the number of laminae. d m1-m3; $\log A W$ logarithm of anterior width, $\log A P$

In the upper dentition the M3 has been used to differentiate the different species of neoepiblemids (Table 1). The case of three small specimens referred to Phoberomys sp. B (AMUCURS 380, AMU-CURS 35 and MCN 66-72 V) is interesting because they have six laminae on M3. The number of laminae on the M3 for Phoberomys ranges between seven and eight (Bondesio and Bocquentin-Villanueva 1988), and Neoepiblema has four laminae (Negri and Ferigolo 1999). We interpret the existence of six laminae in the M3 of small specimens assigned to Phoberomys as an indication of either the possibility of addition of at least one laminae in the M3 during growth or as a higher variability in this area of dental anatomy than currently recognized.

\section{Conclusion}

A higher diversity of giant rodents in the Urumaco Formation is reported with the finding of Neoepiblema sp. There have been questions about the validity of the several neoepiblemid species currently recognized. Our dental and quantitative analysis of Neoepiblemidae shows a differentiation between Phoberomys and Neoepiblema, although both genera fall within the same trajectory. Within Neoepiblema, $N$. horridula is smaller than N. ambrossetianus; the differentiation on size between the two species of Neoepiblema suggest that they are both valid taxa. In contrast, in Phoberomys there is not a clear differentiation among the different species recognized for the genus, suggesting that some could represent different ontogenetic stages of one or a few taxa.

logarithm of anterposterior length. Solid line regression line for log $\mathrm{AW}$ vs. $\log \mathrm{AP}, R^{2}$ value indicated in each panel; dashed line isometric line

Acknowledgments We thank the authorities at the Instituto del Patrimonio Cultural of the Republica Bolivariana de Venezuela and the Alcaldía Municipio de Urumaco for their generous support. Gina Ojeda (CIAAP-UNEFM), Hyram Moreno (MCNC), A. Kramarz (MACN) and M. Reguero (MLP) provided access to the collections under their care. We are thankful to R. Sánchez, A.A. Carlini and J.D. Carrillo-Briceño for their support and help during fieldwork in Urumaco and T. Scheyer and C. Kolb for help and advice with the teeth sectioning, and J.D. Carrillo-Briceño for geographic information. C. Kolb helped with the German abstract. We dedicate this work to Rodolfo Sánchez, to honor his more than 30 years of palaeontological exploration in Urumaco. He kindly provided stratigraphic information on most of the specimens reported here. We thank M.G Vucetich, C. Deschamps (La Plata) and members of the group of Evolutionary Morphology and Paleobiology of Vertebrates (Zurich) for their comments and discussions as well as M.E. Pérez and an anonymous reviewer for valuable comments that helped to improve the manuscript. J.D. Carrillo was supported by Swiss National Fund SNF 31003A-149605 to M.R. Sánchez-Villagra.

\section{References}

Ameghino, F. 1889. Contribución al conocimiento de los mamíferos fósiles de la República Argentina. Boletín de la Academia Nacional de Ciencias de Córdoba 6: 1-127.

Antoine, P.-O., L. Marivaux, D.A. Croft, G. Billet, M. Ganerod, C. Jaramillo, T. Martin, et al. 2012. Middle Eocene rodents from Peruvian Amazonia reveal the pattern and timing of caviomorph origins and biogeography. Proceedings of the Royal Society B: Biological Sciences 279(1732): 1319-1326. doi:10.1098/rspb. 2011.1732.

Bennett, E.T. 1833. On the Chinchillidae, a family of herbivorous Rodentia, and on a new genus referrible to it. The Transactions of the Zoological Society of London 1(1): 35-64. doi:10.1111/j. 1096-3642.1835.tb00602.x.

Blanga-Kanfi, S., H. Miranda, O. Penn, T. Pupko, R.W. DeBry, and D. Huchon. 2009. Rodent phylogeny revised: analysis of six 
nuclear genes from all major rodent clades. BMC Evolutionary Biology 9: 71. doi:10.1186/1471-2148-9-71.

Bocquentin-Villanueva, J., J.P. Souza-Filho, and F.R. Negri. 1990. Neoepiblema acreensis, sp. n. (Mammalia, Rodentia) do Neógeno do Acre, Brasil. Bol Mus Para Emílio Goeldi, sér Ciencias 2: 65-72.

Bondesio, P., and J. Bocquentin-Villanueva. 1988. Novedosos restos de Neoepiblemidae (Rodentia, Hytricognathi) del Mioceno tardío de Venezuela: inferencias paleoambientales. Ameghiniana 25(1): 31-37.

Bowdich, T.E. 1821. An analysis of the natural classifications of Mammalia for the use of students and travelers. Paris: Smith.

Campbell, K.E. 2004. The Paleogene mammalian fauna of Santa Rosa, Amazonia Perú. Natural History Museum of Los Angeles County, Sciences Series 40: 1-163.

Carrillo, J.D., A. Forasiepi, C. Jaramillo, and M.R. Sánchez-Villagra. 2015. Neotropical mammal diversity and the Great American biotic interchange: spatial and temporal variation in South America's fossil record. Frontiers in Genetics 5: 451. doi:10. 3389/fgene.2014.00451.

Cione, A.L., M.M. Azpelicueta, M. Bond, A.A. Carlini, J.R. Casciotta, M.A. Cozzuol, M. de la Fuente, et al. 2000. Miocene vertebrates from Entre Ríos province, eastern Argentina. Insugeo, Serie de Correlación Geológica 14: 191-237.

Cozzuol, M.A. 2006. The Acre vertebrate fauna: age, diversity, and geography. Journal of South American Earth Sciences 21(3): 185-203. doi:10.1016/j.jsames.2006.03.005.

Deschamps, C.M., I. Olivares, E.C. Vieytes, and M.G. Vucetich. 2007. Ontogeny and diversity of the oldest capybaras (Rodentia: Hydrochoeridae; late Miocene of Argentina). Journal of Vertebrate Paleontology 27(3): 683-692. doi:10.1671/02724634(2007)27[683:OADOTO]2.0.CO;2.

Deschamps, C.M., M.G. Vucetich, C.I. Montalvo, and M.A. Zárate. 2013. Capybaras (Rodentia, Hydrochoeridae, Hydrochoerinae) and their bearing in the calibration of the late Miocene-Pliocene sequences of South America. Journal of South American Earth Sciences 48: 145-158. doi:10.1016/j.jsames.2013.09.007.

Fabre, P.-H., L. Hautier, D. Dimitrov, and E.P. Douzery. 2012. A glimpse on the pattern of rodent diversification: a phylogenetic approach. BMC Evolutionary Biology 12(1): 88.

Flynn, J.J., R. Charrier, D.A. Croft, P.B. Gans, T.M. Herriott, J.A. Wertheim, and A.R. Wyss. 2008. Chronologic implications of new Miocene mammals from the Cura-Mallín and Trapa Trapa formations, Laguna del Laja area, south central Chile. Journal of South American Earth Sciences 26: 412-423. doi:10.1016/j. jsames.2008.05.006.

Geiger, M., L.A.B. Wilson, L. Costeur, R. Sánchez, and M.R. Sánchez-Villagra. 2013. Diversity and body size in giant caviomorphs (Rodentia) from the northern Neotropics-a study of femoral variation. Journal of Vertebrate Paleontology 33(6): 1449-1456. doi:10.1080/02724634.2013.780952.

Head, J.J., M.R. Sánchez-Villagra, and O.A. Aguilera. 2006. Fossil snakes from the Neogene of Venezuela (Falcón State). Journal of Systematic Palaeontology 4(3): 233-240. doi:10.1017/ S1477201906001866.

Horovitz, I., M.R. Sánchez-Villagra, T. Martin, and O.A. Aguilera. 2006. The fossil record of Phoberomys pattersoni Mones 1980 (Mammalia, Rodentia) from Urumaco (Late Miocene, Venezuela), with an analysis of its phylogenetic relationships. Journal of Systematic Palaeontology 4(03): 293-306. doi:10.1017/ S1477201906001908.

Horovitz, I., M.R. Sánchez-Villagra, M.G. Vucetich, and O.A. Aguilera. 2010. Fossil rodents from the late Miocene Urumaco and middle Miocene Cumaca Formations, Venezuela. In Urumaco and Venezuelan paleontology. The fossil record of the Northern Neotropics. Life of the past, ed. M.R. Sánchez-
Villagra, O.A. Aguilera, and A.A. Carlini, 214-232. Bloomington and Indianapolis: Indiana University Press.

Huchon, D., P. Chevret, U. Jordan, C.W. Kilpatrick, V. Ranwez, P.D. Jenkins, J. Brosius, and J. Schmitz. 2007. Multiple molecular evidences for a living mammalian fossil. Proceedings of the National Academy of Sciences 104(18): 4795-7499. doi:10. 1073/pnas.0701289104.

Kay, R.F., R.H. Madden, R.L. Cifelli, and J.J. Flynn. 1997. Vertebrate paleontology in the neotropics. The Miocene fauna of La Venta, Colombia. Washington and London: Smithsonian Institution Press.

Kerber, L., F.R. Negri, A.M. Ribeiro, M.G. Vucetich, and J.P. De Souza-Filho. 2015. Late Miocene potamarchine rodents from southwestern Amazonia, Brazil, with description of new taxa. Acta Palaeontologica Polonica. doi:10.4202/app.00091.2014 (in press).

Kraglievich, L. 1926. Los grandes roedores terciarios de la Argentina y sus relaciones con ciertos géneros pleistocenos de Las Antillas. Anales del Museo Nacional de Historia Natural 34: 121-235.

Kraglievich, L. 1932. Diagnosis de nuevos géneros y especies de roedores cávidos y eumegámidos fósiles de Argentina. Anales de la Sociedad Cientifica Argentina 114:155-181 and 211-237.

Kraglievich, L. 1940. Descripción detallada de diversos roedores argentinos terciarios clasificados por el autor. In: A. Torcelli and C.A. Marelli (eds), Obras completas y trabajos científicos inéditos de Lucas Kraglievich. Obras de Geología y Paleontología 2: 297-330.

Kramarz, A.G., and E.S. Bellosi. 2005. Hystricognath rodents from the Pinturas Formation, Early-Middle Miocene of Patagonia, biostratigraphic and paleoenvironmental implications. Journal of South American Earth Sciences 18: 199-212. doi:10.1016/j. jsames.2004.10.005.

Kramarz, A.G., M.G. Vucetich, and M. Arnal. 2013. A new early Miocene chinchilloid Hystricognath rodent; an approach to the understanding of the early chinchillid dental evolution. Journal of Mammalian Evolution 20(3): 249-261. doi:10.1007/s10914012-9215-0.

Linares, O.J. 2004. Bioestratigrafía de la fauna de mamíferos de las Formaciones Socorro, Urumaco y Codore (Mioceno medioPlioceno temprano) de la región de Urumaco, Falcón, Venezuela. Paleobiologia Neotropical 1: 1-26.

MacFadden, B.J. 2006. Extinct mammalian biodiversity of the ancient New World tropics. Trends in Ecology and Evolution 21(3): 157-165. doi:10.1016/j.tree.2005.12.003.

MacPhee, R.D.E. 2011. Basicranial morphology and relationships of Antillean Heptaxodontidae (Rodentia, Ctenohystrica, Caviomorpha). Bulletin of the American Museum of Natural History. doi:10.1206/0003-0090-363.1.1.

MacPhee, R. D. E., and C. Flemming. 2003. A possible Heptaxodontine and other Caviidan rodents from the Quaternary of Jamaica. American Museum Novitates:1-42. doi:10.1206/00030082(2003)422<0001:APHAOC $>2.0 . C O ; 2$.

Mares, M.A., and R.A. Ojeda. 1982. Patterns of diversity and adaptation in South American hystricognath rodents. In Mammalian Biology in South America, eds. M.A. Mares, and H. Genoways, 393-432. The University of Pittsburgh. Special Publication Series (PymItuning Laboratory of Ecology).

Millien, V., and H. Bovy. 2010. When teeth and bones disagree: body mass estimation of a giant extinct rodent. Journal of Mammalogy 91(1): 11-18. doi:10.1644/08-MAMM-A-347R1.1.

Mones, A. 1980. Un neoepiblemidae del Plioceno medio (Formación Urumaco) de Venezuela (Mammalia: Rodentia: Caviomorpha). Ameghiniana 17(3): 277-279.

Mones, A., and P.M. Toledo. 1989. Primer hallazdo de Euphilus Ameghino, 1889 (Mammalia: Rodentia: Neoepiblemidae) en el Neogeno del Estado de Acre, Brasil. Comunicaciones 
Paleontologicas del Museo de Historia Natural de Montevideo 21(2): 1-15.

Moreno, J.F., A.J.W. Hendy, L. Quiroz, N. Hoyos, D.S. Jones, V. Zapata, S. Zapata, et al. 2015. Revised stratigraphy of Neogene strata in the Cocinetas basin, La Guajira, Colombia. Swiss Journal of Paleontology 134(1): 1-39. doi:10.1007/s13358-0150071-4.

Nasif, N.L., A.M. Candela, L. Rasia, M.C. Madozzo-Jaén, and R. Bonini. 2013. Actualización del conocimiento de los roedores del Mioceno tardío de la Mesopotamia argentina: aspectos sistemáticos, evolutivos y paleobiogeográficos. Ascociación Paleontológica Argentina, Publicación Especial 14: 153-169.

Negri, F.R., and J. Ferigolo. 1999. Anatomia craniana de Neoepiblema ambrosettianus (Ameghino, 1889) (Rodentia, Caviomorpha, Neoepiblemidae) do Mioceno Superior-Plioceno, Estado do Acre, Brasil e revisao das especies do genero. Boletim do Museu Paraense Emilio Goeldi, Série Ciências da Terra 11: $1-80$.

Opazo, J.C. 2005. A molecular timescale for caviomorph rodents (Mammalia, Hytricognathi). Molecular Phylogenetics and Evolution 37(3): 932-937. doi:10.1016/j.ympev.2005.05.002.

Pascual, R., and M.L. Díaz de Gamero. 1969. Sobre la presencia del género Eumegamys (Rodentia, Caviomorpha) en la Formación Urumaco del Estado Falcón (Venezuela). Su significación cronológica Asociación Venezolana de Geología, Minas y Petróleo, Boletín Informativo 12: 367-388.

Patterson, B. 1942. Two tertiary mammals from northern South America. American Museum Novitates 1173: 1-7.

Pérez, M.E., and D. Pol. 2012. Major radiations in the evolution of caviid rodents: reconciling fossils, ghost lineages, and relaxed molecular clocks. PLoS One 10: e48380. doi:10.1371/journal. pone. 0048380 .

Quiroz, L., and C. Jaramillo. 2010. Stratigraphy and sedimentary environments of Miocene shallow to marginal marine deposits in the Urumaco trough, Falcón Basin, Western Venezuela. In Urumaco and Venezuelan paleontology. The fossil record of the Northern Neotropics, ed. M.R. Sánchez-Villagra, O.A. Aguilera, and A.A. Carlini, 153-172. Bloomington and Indianapolis: Indiana University Press.

R Core Team. 2014. R: a language and environment for statistical computing. R Foundation for Statistical Computing, Vienna, Austria. http://www.R-project.org/. Accessed 8 Sep 2014.

Ribeiro, A.M., R.H. Madden, F.R. Negri, L. Kerber, A.S. Hsiou, and K.A. Rodrigues. 2013. Mamíferos fósiles y biocronología en el suroeste de la Amazonia, Brasil. Asociación Paleontológica Argentina, Publicación Especial 14: 207-221.

Rinderknecht, A., and R.E. Blanco. 2008. The largest fossil rodent. Proceedings of the Royal Society B: Biological Sciences 275(1637): 923-928. doi:10.1098/rspb.2007.1645.

Sánchez-Villagra, M.R., O. Aguilera, and I. Horovitz. 2003. The anatomy of the world's largest extinct rodent. Science 301(5640): 1708-1710. doi:10.1126/science.1089332.

Sánchez-Villagra, M.R., O.A. Aguilera, and A.A. Carlini. 2010. Urumaco and Venezuelan paleontology. The fossil record of the Northern Neotropics. Life of the past. Bloomington and Indianapolis: Indiana University Press.

Scheyer, T.M., O.A. Aguilera, M. Delfino, D.C. Fortier, A.A. Carlini, R. Sánchez, J.D. Carrillo-Briceno, L. Quiroz, and M.R. SánchezVillagra. 2013. Crocodylian diversity peak and extinction in the late Cenozoic of the northern Neotropics. Nature communications 4: 1907. doi:10.1038/ncomms2940.
Silva Taboada, G., W. Suárez Duque, and D.F. Stephen. 2007. Compendio de los mamíferos terrestres autóctonos de Cuba vivientes y extinguidos. La Habana: Museo Nacional de Historia Natural.

Tejada-Lara, J., R. Salas-Gismondi, F. Pujos, M. Baby, M. Benammi, S. Brusset, D. De Franceschi, N. Espurt, M. Urbina, and P.-O. Antoine. 2015. Life in proto-Amazonia: middle Miocene mammals from the Fitzcarrald Arch (Peruvian Amazonia). Palaeontology 58(2): 341-378. doi:10.1111/pala.12147.

Tullberg, T. 1889. Über das System der Nagetiere, eine phylogenetische Studie. Nova Acta Regiae Societatis Scientiarum Upsalensis III: $1-514$.

Upham, N.S., and B.D. Patterson. 2012. Diversification and biogeography of the Neotropical caviomoprh lineage Octodontoidea (Rodentia: Hytricognathi). Molecular Phylogenetics and Evolution 63: 417-429. doi:10.1016/j.ympev.2012.01.020.

Voloch, C.M., J.F. Vilela, L. Loss-Oliveira, and C.G. Schrago. 2013. Phylogeny and chronology of the major lineages of New World hystricognath rodents: insights on the biogeography of the Eocene/Oligocene arrival of mammals in South America. BMC Research Notes 6: 160. doi:10.1186/1756-0500-6-160.

Vucetich, M.G., M.M. Mazzoni, and U.F.J. Pardiñas. 1993. Los roedores de la Formación Collón Curá (Mioceno Medio) y la ignimbrita Pilcaniyeu, Cañadón del Tordillo, Neuquén. Ameghiniana 30(4): 361-381.

Vucetich, M.G., D.H. Verzi, and J.-L. Hartenberger. 1999. Review and analysis of the radiation of the South American Hystricognathi (Mammalia, Rodentia). Comptes Rendus de l'Academie des Sciences 329: 763-769.

Vucetich, M.G., C.M. Deschamps, A.I. Olivares, and M.T. Dozo. 2005. Capybaras, size, shape, and time: a model kit. Acta Palaeontologica Polonica 50(2): 259-272.

Vucetich, M.G., E.C. Vieytes, M.E. Pérez, and A.A. Carlini. 2010a. The rodents from La Cantera and the early evolution of caviomorphs in South America. In The paleontology of Gran Barranca, ed. R.H. Madden, A.A. Carlini, M.G. Vucetich, and R.F. Kay, 193-205. Cambridge: University of Cambridge Press.

Vucetich, M.G., A.G. Kramarz, and A.M. Candela. 2010b. Colhuehuapian rodents from Gran Barranca and other Patagonian localities: state of the art. In The paleontology of Gran Barranca, ed. R.H. Madden, A.A. Carlini, M.G. Vucetich, and R.F. Kay, 206-219. Cambridge: University of Cambridge Press.

Vucetich, M.G., A.A. Carlini, O. Aguilera, and M.R. SánchezVillagra. 2010c. The tropics as reservoir of otherwise extinct mammals: the case of rodents from a new Pliocene faunal assemblage from Northern Venezuela. Journal of Mammalian Evolution 17(4): 265-273. doi:10.1007/s10914-010-9142-x.

Vucetich, M.G., M.T. Dozo, M. Amal, and M.E. Pérez. 2014. New rodents (Mammalia) from the late Oligocene of Cabeza Blanca (Chubut) and the first rodent radiation in Patagonia. Historical Biology 27(2): 236-257. doi:10.1080/08912963.2014.883506.

Weisbecker, V., and S. Schmid. 2007. Autopodial skeletal diversity in hystricognath rodents: functional and phylogenetic aspects. Mammalian biology-Zeitschrift für Säugetierkunde 72(1): 27-44. doi:10.1016/j.mambio.2006.03.005.

Wood, A.E., and B. Patterson. 1959. The rodents of the Deseadan Oligocene of Patagonia and the beginnings of South American rodent evolution. Bulletin of the Museum of Comparative Zoology 120: 281-428. 